\title{
AFTERWORD: CONTRACTS AND UNCERTAINTY
}

\author{
Walter F. Pratt, JR.*
}

I

\section{INTRODUCTION}

This symposium reveals an unexpected irony: ' The very innovations designed to deal with one type of uncertainty-economic-have themselves produced another type of uncertainty - that associated with resolving disputes. This new uncertainty sounds a discordant note in the traditional refrain that contracts are legal devices for allocating risks between parties. As an afterword, this article draws together evidence from the symposium and from history to emphasize that contract is not the ideal device for allocating risks at the very time that allocation is most desired-when uncertainty is greatest. ${ }^{2}$ The lesson can be put in starker terms: Contract is a legal relationship and therefore too rigid for parties facing significant uncertainty.

To be sure, parties possess substantial freedom to order their relationships by contract. Moreover, according to one basic tenet of contract law, courts will enforce the obligations of contracts (the allocation of risks chosen by the parties). After all, "pacta sunt servanda"-contracts are to be enforced. That doctrine is not alone, however, in guiding courts, and arbitrators as well. There is a competing doctrine that there can be no contract, no legal relationship, if any term essential for determining a remedy is missing. ${ }^{3}$ In other words, at the same time

Copyright $(1983$ by Law and Contemporary Problems

* Associate Professor of Law, Duke University.

1. Some might find irony in the repeated warnings that the innovative construction techniques involve additional cost. Although those warnings have their own irony, the costs should have been expected. Only the most naive would truly expect that innovation and experimentation could come without any cost whatsoever. There is also no unexpected irony in the fact that the costs associated with one of the two primary innovations-design-build/fast track-were said by one participant to have been so great that the innovation is no longer in favor now that interest rates have declined.

2. This afterword does not attempt to resolve the practical or philosophical problems that arise from this conclusion. This symposium was designed to provide practical guidance for the construction industry; this is not the place for inquiry into philosophical problems of contract doctrine. Those interested in practical solutions should study the preceding articles with especial attention to Coulson, Dispute Management Under Modem Construction Systems, LAW \& CoNTEMP. PROBS., Winter 1983, at 127. His discussion of mediation as a means of resolving disputes may point the way toward the sort of flexible method that is required when parties agree to have a relationship that takes shape only as the project develops.

3. The text emphasizes that contract is a legal relationship. Regardless of the intricacy of the parties' agreement, there can be no contract unless a court will enforce the agreement. Enforcement, the legal relationship, depends upon there being enough information in the agreement for the court to fashion a remedy. Without that sufficient information there may be an agreement, but there is no contract, no legal relationship. That fact is evidenced by the definition of "contract" in both the Uniform Commercial Code $\S 1-201(11)$ and the Restatement (Second) of Contracts $\S 1$. Both the UCC and the Restatement emphasize the necessity of adequate information about remedies before there can be a contract. Section 2-204(3) of the UCC states that an agreement should be enforced as a contract, even though there may be omitted 
that courts profess willingness to allow great freedom to contracting parties, the courts require that the freedom be exercised within certain boundaries. It is the absence of those certain boundaries in times of greatest uncertainty that calls into question the utility of contract for allocating risks.

This symposium provides abundant evidence that the contractual innovations have produced an uncertainty of their own-uncertainty regarding the legal relationships between the parties. In Robert Coulson's words, "The advent of the new approaches to construction-fast tracking, design-build, and construction management-brings more uncertainty into the construction process, since many specifics are not determined at the time the contracts are signed." That uncertainty has, in turn, produced an inability to be confident about the outcome of litigation. "At this stage in the development of the law relating to construction management," according to Stanley Bynum, "it is impossible to state a general rule or, in most jurisdictions, to predict a result with reasonable certainty." 5 The result has been a marked change from the predictable world of form contracts that so dominate the construction field - a world in which various clauses are readily compatible with others and in which parties and adjudicators alike have come to understand the meaning of the various provisions. Robert Coulson emphasized that same point when he contrasted the legal documents for fast track construction (most of which are developed as the construction proceeds) with the standard form documents, which "have been tested frequently in both arbitration and in the courts." 6

The resulting uncertainty is in part the product of the attempted use of provisions from standard contracts without carefully thinking through the implications. But the problem goes beyond that relatively easily remedied difficulty. (All that would be needed would be for the industry to develop new standard forms. ${ }^{7}$ ) The more severe problem is that the industry does not want to develop a new standard form for the construction manager or for fast track construction. Instead, it wants

terms, so long as "there is a reasonably certain basis for giving an appropriate remedy." The comparable provision in the Restatement is $\S 33$, which states that the "terms of a contract are reasonably certain if they provide a basis for determining the existence of a breach and for giving an appropriate remedy." RESTATEMENT (SECOND) OF CONTRACTS $\$ 33(2)$ (1979); see also U.C.C. \$ 2-719 comment 1; RestateMENT (SECOND) OF CONTRACTS, supra, $§ 362$ comment a.

4. Coulson, supra note 2, at 127.

5. Bynum, Construction Management and Design-Build/Fast Track Constnuction from the Perspective of a General Contractor, LAW \& CONTEMP. PROBS., Winter 1983, at 25, 30; see also Coulson, supra note 2, at 131-32; Tieder \& Cox, Constnuction Management and the Specially Trade (Prime) Contractors, LAW \& ConTEMP. Probs., Winter 1983 , at 39,45 .

6. Coulson, supra note 2, at 132; cf. Conner, Contracting for Construction Management Services, LAW \& CONTEMP. Probs., Winter 1983, at 5, 9-12.

Some uncertainty is inevitable in any construction project, and the parties recognize that there will be changes in any project while the construction proceeds. Cf. Bynum, supra note 5, at 37; Tieder \& Cox, supra note 5, at 45. Indeed, in their note, Brett Gladstone and Deborah Hartzog emphasize the likelihood of changes when they quote one author as saying that "construction is a form of legalized gambling." Note, Allocation of Risk in the Construction Industry: The Nonprofessional Owner and His Construction Manager, Law \& CONTEMP. PROBS., Winter 1983, at 145, 145. The text only emphasizes that there has been added uncertainty when parties have used new contractual devices to respond to inflation.

7. As Justin Sweet illustrated, however, different groups within the construction industry may have competing interests which prevent the development of standard documents for use throughout the industry. Sweet, The Architectural Profession Responds to Construction Management and Design-Build: The Spotlight on AlA Documents, LaW \& ConTemp. Probs., Winter 1983, at 69. 
to keep the concepts loosely defined to permit a flexible response to the perplexing changes in the economic climate.

There is little inherently wrong with retaining substantial flexibility-so long as the parties do not desire to create a legal relationship. There can, however, be significant difficulties in attempting to create a legal relationship out of whole cloth such as the concept of construction management. As this article will illustrate shortly, history teaches that the uncertainty of litigation will be even greater when the parties choose to leave their relationship ill-defined. Yet that lack of definition is precisely the problem that Randy Squires and Michael Murphy identified as persisting in the fast track process. ${ }^{8}$

Another example of the problem of definition is the use of the single term "construction manager" in contracts even though the provisions of the different contracts define the term in varying ways. That repetition can only serve to invite problems of interpretation by courts and arbitrators. ${ }^{9}$ The problems that may arise are analogous to those illustrated by Richard Connor when he referred to courts that labor under stereotypical notions of the relationship between architects and owners in determining the liabilities of architects. ${ }^{10}$ Repeated use of the same term risks creating the perception that the same relationship is intended in each contract. Courts faced with myriad new relationships might be excused if they misinterpret a custom-made relationship as a traditional one.

Again, though, the problem is more serious than that rather simple example of an adjudicator's failure to attend to the terms of the contract. The problem is one endemic to contract law: There will be fateful uncertainty when the parties are unable to provide courts with standards by which to interpret language of contracts. If the language of the contract cannot be made certain-and almost by definition it cannot be certain when the parties want to leave significant opportunities to respond to economic changes-then courts can turn only to the conduct of the parties or to the habits of the industry for guidance in construing the language. If neither the parties nor the industry have developed useful patterns, then the courts will be left without any standard, and litigation will produce only further uncertainty. ${ }^{11}$ As the remaining portion of this afterword illustrates, the absence of a standard in the nineteenth century might have resulted only in a court's refusal to enforce a contract. Today's courts are more likely to enforce contracts, though substantial gaps still prove troublesome. The increased likelihood of enforcement does not, however, afford much solace to the construction industry.

8. Squires \& Murphy, The Impact of Fast Track Construction and Construction Managernent on Subcontractors, LaW \& CONTEMP. Probs., Winter 1983, at 55; see also Grinnell Fire Protection Sys. Co. v. W.C. Ealy \& Assocs., 552 S.W.2d 747 (Tenn. 1977).

9. Bynum, supra note 5, at 28; Foster, Construction Management and Design-Build/Fast Track Construction: A Solution Which Uncovers a Problem for the Surety, LAW \& CONTEMP. Probs., Winter 1983, at 95, 104. Squires \& Murphy, supra note 8, at 55, 64-65; Tieder \& Cox, supra note 5, at 42-43; There is no agreement on the definition of the construction manager. Lunch, New Construction Methods and New Roles for Engineers, LAw \& Contemp. Probs., Winter 1983, at 83, 83-84.

10. Connor, supra note 5 , at text accompanying note 8 .

11. Cf. U.C.C. $\S \S 1-205,2-208$ ("course of dealing," "usage of trade," and "course of performance" used to interpret terms of contracts); RESTATEMENT (SECOND) OF CONTRACTS $\S \S 202.220$ (1979) (semble). 
Courts are now more likely to consider societal norms in construing private contracts. Although the result might be that the "contract" is enforced, the norms might be very different from the ones that the parties themselves would have chosen. Therefore, the construction industry, by eschewing certainty in its legal relationships, may find that it is held to standards which may very much differ from those the industry would select.

\section{A BRIEF History}

The efforts of the construction industry to grapple with the coincidence of substantive uncertainty and doctrinal uncertainty are remarkably similar to developments in contract law at the end of the nineteenth century and the beginning of the twentieth century. During that period-roughly from 1870 to 1920 - the interplay between uncertainty both about the economy and about contract doctrine caused significant problems for those who looked to contract as a means of allocating risks.

The particular economic uncertainty was about markets, the result of the development of new industries which, along with already established manufacturers, sought to expand their markets throughout the nation rather than in a single region. Merchants in the late nineteenth century were likely to adopt the same wait-and-see attitude that characterizes the innovations in today's construction industry. Typically, the parties did not fix the quantity term in the contract. Instead, they were content to await developments, either of supply or of demand, and then set the quantity term. For example, a seller which was uncertain about its ability to predict the production schedule for a new product wanted to avoid a fixed obligation to sell. That seller would try to find a buyer willing to contract to purchase all that the seller could produce_an "output" contract. ${ }^{12}$ Similarly, a buyer who was uncertain of the demand for a new product or of the new market for an established product hoped to find a seller who would agree to sell all that the buyer would order-a "requirements" contract. ${ }^{13}$ A variation on those con-

12. In some instances the new means of production required a certain source of raw materials to ensure that the production would be profitable. One instance involved a new cannery; for the cannery to be profitable, there had to be a guaranteed source of supply for the vegetables. The court explained that a contract under which a farmer promised to deliver his crop of corn was to the mutual benefit of both parties. The cannery gained assurance of its supply; the farmer gained assurance of a market. As the court explained, there was evidence that "corn fit for this purpose [canning] could not be obtained in the open market in sufficient quantities to authorize the necessary expense in building, machinery and preparations required to carry on this business, but that to make it a prudent and safe business resort must be had to contracts like the one under consideration." J. Winslow Jones \& Co. v. Binford, 74 Me. 439, 444 (1883); cf. Fontaine v. Baxley, Boles \& Co., $90 \mathrm{Ga} .416$, 426, 17 S.E. 1015, 1018 (1892) (requirements contract for railroad ties beneficial to both parties).

On the development of industry generally, see Chandler, The Beginnings of "Big Business" in American Industry, 33 Bus. Hist. REv. 1 (1959); McCurdy, American Law and the Marketing Structure of the Large Corporaiion, 1875-1890, 38 J. ECON. HIST. 631 (1978).

13. S. Ratner, J. Soltow \& R. Sylla, The Evolution of the American Economy 375-78 (1979) (development of wholesalers, etc.); $f$. Havighurst \& Berman, Requirement and Output Contracts, 27 ILL. L. REV. 1,1 (1932) (uncertainties lead to new types of contracts). The court in Bloomington Canning Co. v. United Can Co., 94 Ill. App. 62, 66 (1901), explained that a requirements contract benefited both parties. The buyer was able to secure a source for its needs without having to fix the quantity; the seller 
tracts was the "exclusive dealing" contract under which the seller agreed to furnish all that the buyer could sell and the buyer agreed to deal only in the products of the seller. This type of contract worked especially well for sellers seeking to introduce products into a new market.

Output and requirements contracts have little history before the Civil War. ${ }^{14}$ They appear to have come into frequent use during the years of rapid economic expansion after the war. With those contracts, however, the businessmen of the nation confronted courts with a challenge to existing doctrine. The traditional rule of contract law was that there could be no contract unless the parties had mutual obligations. ${ }^{15}$ Under that rule, a contract that left the quantity term open provided no immediate evidence of mutuality. An output contract obligated the buyer to purchase whatever quantity the seller produced; but, some reasoned, there was no obligation on the part of the seller to have any production. Likewise, a requirements contract obligated the seller to sell whatever quantity the buyer ordered; but the buyer had no obligation to have any orders. At a time when sellers of new products had no established record of production and when the new markets had no established record of orders, the judges had no standards for determining damages. The result was that for a number of years the courts provided no predictable response to output or requirements contracts.

An early case that came to be cited frequently was Bailey $v$. Austrian. ${ }^{16}$ That case involved an agreement dated 1871 for the supply of all the Lake Superior pig

was able to estimate its needs for raw materials. See also Golden Cycle Mining Co. v. Rapson Coal Mining Co., 188 F. 179, 180 (8th Cir. 1911) (new ore reduction works needed continuous supply of coal in 1906); Connersville Wagon Co. v. McFarlan Carriage Co., 166 Ind. 123, 124, 76 N.E. 294, 295 (1905) (McFarlan could sell as many carriages as it could manufacture. It needed a certain supply of wheels, yet all wheel manufacturers were operating at full capacity); Rehm-Zeiher Co. v. F.G. Walker Co., 156 Ky. 6,160 S.W. 777 (1913) (whiskey); Cullinan v. Standard Light \& Power Co., 65 S.W. 689, 690 (Tex. Civ. App. 1901) (oil).

14. Havighurst \& Berman, supra note 13, at $1 \mathrm{n} .1$ ("The only case found in this country prior to the middle of the nineteenth century involving a contract of the type considered in this article without a fixed quantity term is Mason v. Cowan's Administrator [40 Ky. 7 (1840)]." The contract, dated November 1836, provided that the buyer would purchase all the hogs the seller "may have for market next fall."). For another early discussion of requirements contracts see Note, The Construction of Requirement Coniracts and the Effect of Estimate Provisions Therein, 28 Colum. L. REv. 223 (1928).

At least one court analyzed a contract to carry iron by rail, up to a limit, as an option contract. Chicago \& Great Eastern Ry. v. Dane, 43 N.Y. 240 (1870).

15. Fallon v. Chronicle Publishing Co., 1 MacArth. 485 (D.C. 1874); Savannah Ice Delivery Co. v. American Refrigerator Transit Co., $110 \mathrm{Ga} .142,35$ S.E. 280 (1900) (dictum); Campbell v. A. Lambert \& Co., 36 La. Ann. 35, 37 (1884) (contract to deliver requirements of coal in 1879); see also American Cotton Oil Co. v. Kirk, 68 F. 791, 793 (7th Cir. 1895); Kenan, McKay \& Spier v. Home Fertilizer \& Cotton Oil Co., 202 Ala. 29, 79 So. 367 (1918); American Refrigerator Transit Co. v. Chilton, 94 Ill. App. 6, 9 (1901). Not all of the early cases held requirements contracts unenforceable. See Smith v. Morse, 20 La. Ann. 220 , 222 (1868) (enforcing contract to supply all the ice required for use in hotel for five years); Cherry v. Smith, 22 Tenn. (3 Humph.) 19, 24 (1842) (enforcing contract to ship up to 150 barrels of salt "when called on").

Later cases tended to provide a further explanation for holding that the contract was unenforceable. Although the courts used the term "want of mutuality", they explained that their conclusion protected one party from being taken advantage of by the other-that the party who was not bound was free to take advantage of changes in the market to take advantage of the other. E.g., Schimmel v. Martin, 190 Cal. $429,432,213$ P. 33, 34 (1923) (contract to supply water; court concludes that it would be unreasonable to construe contract as promise to supply water indefinitely at single price in agreement); Campbell v. American Handle Co., 117 Mo. App. 19, 24, 94 S.W. 815, 816 (1906); see also infra note 32.

16. 19 Minn. 535 (1873). See generally Lavery. The Doctrine of Bailey v. Austrian, 10 Min.s. L. REv. 584 (1926). 
iron that the plaintiff would "want" during a particular period. The Supreme Court of Minnesota reasoned that there was no mutuality because the plaintiff had not promised to "want" any pig iron. There was therefore no contract on which the plaintiff could recover. For the following quarter of a century the courts of the country provided no certain response to output or requirements contracts; some followed Bailey, some did not. ${ }^{17}$

By the first years of the twentieth century, however, the pattern had changed. In part the change was the result of the sheer number of cases-cases in which one can almost hear the economic development of the country. Iron and bolts are needed from a Kansas City manufacturer; ${ }^{18}$ wheels are needed in Michigan ${ }^{19}$ and in Indiana; ${ }^{20}$ fertilizers and phosphates are required in Pennsylvania ${ }^{21}$ and in Virginia; $;^{22}$ and railroad ties are needed throughout the country. ${ }^{23}$ The effect of that cacophony of development was to crush the doctrinal formalism that had held the agreements to be lacking in mutuality and therefore unenforceable. The courts simply could not withstand the repeated evidence that business actually used the contracts, however lacking in mutuality they might seem. To refuse to enforce the contracts would, in the words of the Missouri Court of Appeals, "introduce inextricable confusion into business transactions." 24 Moreover, the later court decisions had come to show "increasing liberality on this point, doubtless for the reason that trade usages have dictated a relaxation from the former strictness." 25

There was a second cause of the doctrinal change: Business began to develop in a way that provided standards by which courts could judge the meaning of terms,

17. Cases following Bailey include A. Santaella \& Co. v. Otto F. Lange Co., 155 F. 719, 723 (8th Cir. 1907); McCaw Mfg. Co. v. Felder \& Rountree, 115 Ga. 408, 413, 41 S.E. 664, 666 (1902); Wickham \& Burton Coal Co. v. Farmers' Lumber Co., 189 Iowa 1183, 1190, 179 N.W. 417, 420 (1920); Tarbox v. Gotzian, 20 Minn. 139, 141 (1873). For examples of cases not following Bailey see Lavery, supra note 16, at 587 n.11.

18. Cold Blast Transp. Co. v. Kansas City Bolt \& Nut Co., 114 F. 77 (8th Cir. 1902).

19. Cooper v. Lansing Wheel Co., 94 Mich. 272, 54 N.W. 39 (1892).

20. Staver Carriage Co. v. Park Steel Co., 220 Ill. 412,77 N.E. 174 (1906); Connersville Wagon Co. v. McFarlan Carriage Co., 166 Ind. 123, 76 N.E. 294 (1905).

21. Aetna Explosives Co. v. Diamond Alkali Co., 277 Pa. 392, 121 A. 201 (1923) (contract for 1916).

22. American Agricultural Chem. Co. v. Kennedy, 103 Va. 171, 48 S.E. 868 (1904) (contract dated 1902); see also Loudenback Fertilizer Co. v. Tennessee Phosphate Co., 121 F. 298 (6th Cir. 1903).

23. Hazelhurst Lumber Co. v. Mercantile Lumber \& Supply Co., 166 F. 191 (C.C.W.D. Mo. 1908); McIntyre Lumber \& Export Co. v. Jackson Lumber Co., 165 Ala. 268, 51 So. 767 (1910); Bagnell Timber Co. v. Spann, 102 Ark. 621, 145 S.W. 546 (1912); Fontaine v. Baxley, Boles \& Co., 90 Ga. 416 , 17 S.E. 1015 (1892); Hudson v. Browning, 264 Mo. 58, 174 S.W. 393 (1915); Laclede Constr. Co. v. T.J. Moss Tie Co., 185 Mo. 25, 84 S.W. 76 (1904).

24. American Publishing \& Engraving Co. v. Walker, 87 Mo. App. 503, 507-08 (1901); see also American Trading Co. v. National Fibre \& Insulation Co., 31 Del. 65, 84, 111 A. 290, 298 (Super. Ct. 1920); Wells v. Alexandre, 130 N.Y. 642, 29 N.E. 142 (1891) (contract for coal required on steamship) (One commentator wrote that this was "[p]erhaps the leading case in support of the validity" of a requirements contract. Note, Contracts_- "Requirements" Contracts_Mutuality of Obligation, 11 NOTRE DAME LAW. 227, 227 (1936)); Excelsior Wrapper Co. v. Messinger, 116 Wis. 549, 555, 93 N.W. 459, 461 (1903)

One court effectively stood the principle of mutuality on its head. After concluding that one party was bound by the contract, the court noted that "the principle of mutuality, which is an essential element of every contract, compels a ruling that the other party shall also be bound by the terms of the contract, in order to make it a binding agreement." Dawson Cotton Oil Co. v. Kenan, McKay \& Speir, 21 Ga. App. 688, 695, 94 S.E. 1037, 1040 (1918); see also Lewis v. Atlas Mut. Life Ins. Co., 61 Mo. 534,538 (1876) (if one party was bound "it necessarily follows that [the other party] must also have been bound").

25. 87 Mo. App. at 508 . 
and even the meaning of intentional gaps in an agreement. ${ }^{26}$ One illustration of the change is a 1901 decision of the Supreme Court of Minnesota, Ames-Brooks Co. v. Aetna Insurance Co. ${ }^{27}$ The dispute in Ames-Brooks arose over a contract to provide insurance on grain shipments on the Great Lakes for the shipping season of 1899 . Aetna had provided insurance in the past and agreed that it would do so for that year. But when the rates for insurance subsequently increased, the Aetna syndicate sought to escape any obligation by arguing that there was no mutuality because Ames-Brooks had not promised to have any shipments during the year. Although the trial court agreed with that contention, the supreme court did not. The supreme court emphasized that it "must interpret the contract from the standpoint of the practical businessmen who made it . . . and the established course of business between them."28 Most important was the court's explanation of the distinction between Bailey and Ames-Brooks: Ames-Brooks was different because it had an established business which required insurance on its cargoes. The court reasoned that because plaintiff's business was established it would continue for another year. Moreover, implicit in the agreement was plaintiff's promise to buy whatever insurance it needed from Aetna and from no one else. ${ }^{29}$ The established record of business satisfied the court that there was sufficient likelihood that there would be a need.

The decision to enforce the contracts only created a new uncertainty to replace the former one. In place of doubt about enforcement came doubt about the extent of the obligation. For example, jobbers might have an established business, but there was no basis on which to set limits on the quantities that the jobbers might order under a requirements contract. ${ }^{30}$ To set limits on the orders courts read

26. See, e.g., T.B. Walker Mfg. Co. v. Swift \& Co., 200 F. 529, 530-31 (5th Cir. 1912); Lima Locomotive \& Mach. Co. v. National Steel Castings Co., 155 F. 77, 79 (6th Cir. 1907); Cold Blast Transp. Co. v. Kansas City Bolt \& Nut Co., 114 F. 77, 79-80 (8th Cir. 1902); Manhattan Oil Co. v. Richardson Lubricating Co., 113 F. 923, 925 (2d Cir. 1902) (buyer must observe good faith in limiting orders to legitimate requirements of business); T.W. Jenkins \& Co. v. Anaheim Sugar Co., 237 F. 278, 279-82, (S.D. Cal. 1916), rev'd, 247 F. 958 (9th Cir. 1918); A. Klipstein \& Co. v. Allen, 123 F. 992 (N.D. Ga. 1903); American Trading Co. v. National Fibre \& Insulation Co., 31 Del. 65, 84, 111 A. 290, 298 (Super. Ct. 1920); Nelson v. Barber, 143 La. 783, 786, 79 So. 403, 404 (1918); Smith v. Morse, 20 La. Ann. 220, 222 (1868) (ice for hotel); E. Richard Meinig Co. v. U.S. Fastener Co., 200 A.D. 522, 531, 193 N.Y.S. 106, 113 (1922) (selfpiercing glove clasps); McCall Co. v. Icks, 107 Wis. 232, 239, 83 N.W. 300, 302 (1900) (McCall patterns).

27. 83 Minn. 346, 350, 86 N.W. 344, 346 (1901); see City of Marshall v. Kalman, 153 Minn. 320, 324, 190 N.W. 597, 599 (1922); Minneapolis Mill Co. v. Goodnow, 40 Minn. 497, $498-99$ (1889); 9 CrClopediA OF LAW AND Procedure, Contracts 330 n.24 (1903). The case has symbolic importance as well, because in it the court tacitly overruled Bailey.

28. Ames-Brooks, 83 Minn. at 349, 86 N.W. at 345; cf. The Kronprinzessin Cecilie, 244 U.S. 12, 24 (1917) ("Business contracts must be construed with business sense, as they naturally would be understood by intelligent men of affairs."); T.B. Walker Mfg. Co. v. Swift \& Co., 200 F. 529, 531 (5th Cir. 1912); Minnesota Lumber Co. v. Whitebreast Coal Co., 160 Ill. 85, 93, 43 N.E. 774, 777 (1895); Warden Coal Washing Co. v. Meyer, 98 Ill. App. 640, 643 (1901); Cincinnati S. \& C. R.R. v. Consolidated Coal \& Mining Co., 8 Ohio Dec. Reprint 365, 367 (Cincinnati Super. Ct. 1882).

Some years later Justice Traynor explained the development of the doctrines of frustration and of impossibility as attributable to "the commercial necessity of excusing performance in cases of extreme hardship." Lloyd v. Murphy, 25 Cal. 2d 48, 53, 153 P.2d 47, 50 (1944).

29. Ames-Brooks, 83 Minn. at 350,86 N.W. at 346 ; $f$. National Furnace Co. v. Keystone Mfg. Co., 110 IIl. 427, 434 (1884); Hickey v. O'Brien, 123 Mich. 611, 614-15, 82 N.W. 241, 242-43 (1900) (court traces process of distinguishing Bailey $v$. Austrian).

30. The cases dealing with jobbers and other middlemen provide additional evidence of the courts shifting their concern from doctrinal stability to fairness to the parties. Jobbers and others like them lacked 
concepts such as "good faith" into the contracts. That requirement, as well as the courts' changed attitude toward contracts for whatever quantity a party might "want," is well illustrated by the following observation of a federal district judge in 1924:

In construing contracts in which persons seek to cover . . . contingencies and uncertainties ... provisions reasonably adapted to that end should not be made futile and meaningless because they may contain some element of the "will, wish, or want" of one of the parties. Into each such stipulation the law will inject the requirement of good faith and fair dealing. Better it is that there should be some indefiniteness and uncertainty in contracts such as these than that the [parties] should be told that, unless they are able accurately to foretell what nature holds in store, they cannot safely make contracts which will in some degree be dependent upon future events. ${ }^{31}$

By the early part of the twentieth century, then, courts were inclined to enforce output and requirements contracts. ${ }^{32}$ That inclination had taken almost a quarter of a century to develop. In the interim, businesses seeking to contract in light of economic uncertainty had faced an equal, if not greater, uncertainty in the courts. Businesses had not known what the law was from jurisdiction to jurisdiction; they also had been uncertain of the stage of doctrinal development within particular jurisdictions.

established customers. They could therefore alter their requirements for goods depending on the market. Crane v. C. Crane \& Co., 105 F. 869, $871-72$ (7th Cir. 1901); Higbie v. Rust, 211 Ill. 333, 337, 71 N.E. 1010 , 1011 (1904); Saginaw Medicine Co. v. Dykes, 210 Mo. App. 399, 405, 238 S.W. 556, 557 (1922); Jackson v. Alpha Portland Cement Co., 122 A.D. 345, 348-49, 106 N.Y.S. 1052, 1055 (1907). But see T.W. Jenkins \& Co. v. Anaheim Sugar Co., 237 F. 278 (S.D. Cal, 1916), rev'd, 247 F. 961 (9th Cir. 1918) (district court held contract lacking in mutuality because buyer was a wholesale dealer who could alter requirements; court of appeals reversed, holding that there was a presumption of integrity of conduct); Fontaine v. Baxley, Boles \& Co., $90 \mathrm{Ga} .416,426,17$ S.E. 1015, 1018 (1892) (manufacturer agreed to supply all railroad ties that middleman might sell; enforced); Oscar Schlegel Mfg. Co. v. Peter Cooper's Glue Factory, 189 A.D. 843, 847,179 N.Y.S. 271, 273 (1919). Not all decisions were alike. When a requirements contract stated both minimum and maximum quantities, a court permitted the buyer to order for resale as well as for its own needs, so long as the orders were within the limits set by the contract. Aetna Explosives Co. v. Diamond Alkali Co., 277 Pa. 392, 121 A. 201 (1923).

31. California Prune \& Apricot Growers, Inc. v. Wood \& Selick, Inc., 2 F.2d 88, 90 (S.D.N.Y. 1924).

32. Although courts rarely questioned the enforceability of the contracts after the turn of the century, they did have to confront the different problems of defining the obligations of the contracts. E.g., In re United Cigar Stores Co., 8 F. Supp. 243, 244 (S.D.N.Y.) (buyer not obligated to stay in business), affd, 72 F.2d 673 (2d Cir.), cert. denied, 293 U.S. 617 (1934); Chalmers v. Walter Bledsoe \& Co., 218 Ill. App. 363, 367.72 (1920) (contract for requirements of coal; buyer changed from steam power to electricity thereby reducing need for coal); C.A. Andrews Coal Co. v. Board of Directors of Pub. Schools, 151 La. 695, 92 So. 303 (1922) (buyer not at liberty to change equipment with effect of increasing requirements); Asahel Wheeler Co. v. Mendleson, 180 A.D. 9, 12, 167 N.Y.S. 435, 438 (1917) (implied obligation of good faith and fair dealing means that buyer cannot order for speculative purposes); McKeever v. Duncan, $138 \mathrm{~Pa}$ 184, 20 A. 938 (1890) (contract for requirements of coal does not preclude buyer from drilling gas well which reduces need for coal).

Professor Friedrich Kessler and Professor Grant Gilmore had the following to say about the developments:

It is surely one of the more discreditable episodes in our history that for a generation or more the argument could be seriously made that there was no contract because the buyer's promise to buy his requirements was 'illusory' and therefore, no consideration for the seller's promise to sell. The eventual triumph of good sense represents, chronologically, one of the earliest instances in which obvious commercial needs and pressures forced the reversal of a position initially based on apparently logical deductions from nineteenth century consideration theory.

F. Késsler \& G. Gilmore, Teacher's Manual Contracts: Cases and Materials 26 (1972). 


\section{III}

\section{NeW UnCERTAinties}

The construction industry faces a similar uncertainty today even though courts may be more willing to accept uncertainty than in the early years of this century. Moreover, the trend toward introducing societal norms such as "good faith" into contracts continues today. The effect of these changes is that though parties may have less concern about whether their contract will be enforced, they may have greater concern about how any gaps will be filled.

The major chronicler of the shift toward an increased role for societal norms in contract law is Professor Patrick Atiyah. ${ }^{33}$ According to Professor Atiyah, contract law today is undergoing a major doctrinal shift away from an emphasis on obligations voluntarily assumed by the parties. In place of that view there is developing an emphasis on "the element of reciprocal benefit and [on] the fact of reliance." 34 If Professor Atiyah is correct, then especially for those contracts that deliberately leave gaps to be filled as the parties proceed, the courts will be likely to fill the gaps with societal norms rather than the norms of the parties.

This is not the place for a full inquiry into Professor Atiyah's description of the changes in the law of contracts. ${ }^{35}$ There are, however, some hints that American law may be moving in the direction that he describes. The hints are no more than that-they are few in number and as yet insignificant in terms of doctrine. But

33. This afterword uses the term "societal norms" as a shorthand means of referring to a more complex phenomenon. This shorthand usage is not meant to suggest that courts have only recently begun to consider the norms of society. Indeed, Professor Atiyah's analysis suggests that the courts have always considered the norms of society when dealing with contracts. What has changed recently is the nature of those norms. In general terms, Professor Atiyah identifies a change from a time when society through its courts saw primary value in enforcing the intentions of individuals. With that as a guiding value, courts enforced contracts with little attention to concerns other than what the parties had negotiated. Today, again in general terms, the intent of the parties may not be of overriding significance. Indeed, notions such as fairness and justice may enter into a court's decision. It is the imposition of those notions, apart from the intentions of the parties, that is meant when the term "societal norms" is used. Professor Atiyah's works include P. Atiyah, The Rise and Fall of Freedom of Contract (1979); P. Atiyah, Promises, Morals, and the Law of Obligations (1981); Atiyah, Contracts, Promises and the Lazes of Obligations, 94 LAW. Q. REv. 193 (1978). Professors Grant Gilmore and Morton Horwitz have published similar interpretations of the American law of contracts. See G. Gilmore, The Death OF Contract (1974); M. HorWITL, The Transformation OF AMERICAN LAw, 1780-1860 (1977); see also Gillette, Limitations on the Obligation of Good Faith, 1981 DUKE L.J. 619; Newman, The Renaissance of Good Faith in Contracting in AngloAmerican Law, 54 Cornell L. REv. 553 (1969). For a general discussion of recent developments in contract law and theory, see Strasser, Contract's "Many Futures" after Death; Unanswered Questions of Scope and Purpose, 32 S.C.L. REv. 501 (1981).

34. Atiyah, Contracts, Promises and the Laws of Obligations, supra note 33, at 221 ; cf. id. at 223 ("[W]hat I do want to suggest is that the great divide between duties which are voluntarily assumed, and duties which are imposed by law is itself one of these oversimplifications. A more adequate and more unifying conceptual structure for the law of obligations can be built around the inter-relationship between the concepts of reciprocal benefits, acts of reasonable reliance, and voluntary human conduct.").

35. Professor Charles Fried has written a book that disagrees with much that Professor Atiyah has argued. C. Fried, Contract as Promise (1981). Professor Fried expressed those disagreements directly in his review of The Rise and Fall of Freedom of Contract. Fried, Book Review, 93 HARV. L. REV. 1858 (1980). In addition, Professor Atiyah's work has been reviewed widely, both with agreement and with disagreement. See, e.g., Black, Book Review, 79 MiCH. L. Rev. 929 (1981) (favorable review of THE RISE ANI) FALL OF FreEDOM OF ContraCT); Collins, Book Review, 45 MOD. L. Rev. 225 (1982) (critical of the argument in Promises, MORALS, AND THE LAW that there has been a resurgence of benefit-based and reliance-based liabilities). 
they may well be harbingers of the future. Furthermore, insofar as construction contracts require the development of new doctrine, those doctrines which emerge are likely to follow the direction of currently developing contract law.

In particular, these hints suggest that some courts, including courts dealing with construction contracts, may prefer to look beyond the intentions of the parties to ask whether there was fairness in the bargaining process or whether one party or the other would be a better bearer of the loss that resulted. ${ }^{36}$ Another group of cases suggests that some courts may come to view long-term contracts as relationships that impose obligations on the parties on account of the reliance by each party that the relationship will continue. ${ }^{37}$ If one party is shown to have relied upon a particular aspect of the contract, then when an unexpected event occurs, the court may be inclined to modify the contract to permit it to continue rather than to enforce the contract as written.

The latter motivation seems to have influenced the court's decision in Aluminum Company of America $v$. Essex Group, Inc. ${ }^{38}$ That case arose out of a contract between Alcoa and Essex under which Alcoa was to convert alumina supplied by Essex into aluminum; the contract was to run from 1967 through 1983, with Essex having an option to extend the contract until 1988. The parties recognized that inflation would increase Alcoa's processing costs; so, after extensive negotiation and consultation with economists, the parties provided that certain components of the price charged by Alcoa would vary according to published economic indexes. The pro-

36. See Asphalt Int'l, Inc. v. Enterprise Shipping Corp., 667 F.2d 261, 266 n.5 (2d Cir. 1981) (In a footnote to a discussion of commercial impracticability the court writes: "The fundamental question involves the appropriate allocation of risk, that should be determined according to which party was in the better position to insure against the various losses occasioned by the collision."); see also $\mathrm{M} \& \mathrm{M}$ Transp. Co. v. Schuster Express, Inc. (In re M \& M Transp. Co.), 13 Bankr. 861, 869 (S.D.N.Y. 1981) (The principle of commercial frustration "is an offshoot of the twentieth century's rejection of a judicial hands-off policy towards contracts. It reflects increased judicial involvement in private contracts . . . . It is an affirmation of the reality that there are situations where society's needs are best served by not enforcing the performance of senseless contracts."); $f f$. Note, supra note 6, at 162-63 (description of judicial resistance to particular allocation of risks).

37. See Neal-Cooper Grain Co. v. Texas Gulf Sulphur Co., 508 F.2d 283, 294 (7th Cir. 1974). ("After one party has entered a contract for supply, he ceases to look for other sources and does not enter other contracts . . . Barring circumstances not existent here, the buyer has a right to rely on the party to the contract to supply him with goods regardless of what happens to the market price. That is the purpose for which such contracts are made."). Professor Macneil has been a prime exponent of the theory that contracts are "relational" - they involve more than single, discrete encounters between the parties. See, e.g., Macneil, Contracts: Adjustment of Long-Tern Economic Relations Under Classical, Neoclassical and Relational Contract Law, 72 Nw. U.L. Rev. 854 (1978); Macneil, A Primer of Contract Planning, 48 S. CAL. L. REv. 627 (1975); Macneil, The Many Futures of Contracts, 47 S. CAL. L. REV. 691 (1974). Professor Speidel has written of the obligations arising from long-term contracts:

In short, the long-term supply contract is a bit more complex than the "one-shot" sale of Dobbin or Blackacre. Beyond its obvious economic importance, it complicates, and perhaps even prevents, complete risk planning at the time of contracting. Complete consent is a mirage. Over time, "gaps" in the initial agreement will undoubtedly emerge. At the same time, specialized uses of the contract will increase both the cost of terminating the relationship and the likelihood that the market will be unable to provide an adequate substitute for either party.

Speidel, Court-Imposed Price Adjustments Under Long-Term Supply Contracts, 76 Nw. U.L. REV. 369, 375 (1981); see also Speidel, Excusable Nonperformance in Sales Contracts: Some Thoughts About Risk Management, $32 \mathrm{~S}$. CA1.. L. REV. 241 (1980).

38. 499 F. Supp. 53 (W.D. Pa. 1980). The case was settled before the Court of Appeals for the Third Circuit could review the decision. Telephone interview with attorney for Essex Group (May 1982) 
vision for varying the price worked reasonably well until 1973, when the OPEC oil embargo dramatically increased the cost of oil and when antipollution costs rose faster than the economic indexes permitted the charge to Essex to rise. Alcoa sought relief from what it contended would be a contract that forced it into increasingly large losses.

Alcoa's suit asked the court to order an equitable modification of the contract price. The court did so, under the theories of mutual mistake of fact, frustration of purpose, and impracticability. ${ }^{39}$ The precise nature of the court's reasoning is not important for purposes of this afterword. ${ }^{40}$ What is important is language pervading the opinion which indicates that the court viewed the significant issue as more than a matter of enforcing the intentions of the parties. For instance, the court observed that courts "must decide that point at which the community's interest in predictable contract enforcement shall yield to the fact that enforcement of a particular contract would be commercially senseless and unjust."41 Further, the court noted that the principle involved in framing a remedy fell not within reformation of a contract as an equitable remedy but within the "more general rules of equitable restitution." 42 The court went on to explain that the principle was one in which "the courts award appropriate restitution in the light of the benefits the parties have conferred on each other. The aim is to prevent unjust enrichment."43 To achieve those goals and to permit the continuation of the contract, the court ordered a modification of the price term. In effect, the court allocated the increased costs incurred by Alcoa between the two parties. ${ }^{44}$

Alcoa and similar cases provide some suggestion of the future of contract doc-

39. Id. at 70 .

40. The Alcoa case has been cited by a number of courts, but never followed. See, e.g., Freidco of Wilmington, Del., Ltd. v. Farmers Bank, 529 F. Supp. 822, 827 n.3 (D. Del. 1981); Louisiana Power \& Light Co. v. Allegheny Ludlum Indus., 517 F. Supp. 1319, 1327 (E.D. La. 1981); /n re Westinghouse Elec Corp. Uranium Contracts Litig., 517 F. Supp. 440, 458 (E.D. Va. 1981); Wabash, Inc. v. Avnet, Inc., 516 F. Supp. 995, 999 n.5 (N.D. Ill. 1981). In addition to Professor Speidel's article in the Northwestern University Law Review, supra note 37, the case has also been discussed in Comment, Relief from Burdensome Longlerm Contracts: Commercial Impracticability, Frustration of Purpose, Mutual Mistake of Fact, and Equitable Adjustment, 47 Mo. L. ReV. 79 (1982).

41. Alcoa, 499 F. Supp. at 76. Judge Skelly Wright used similar langage when writing for the court in Transatlantic Fin. Corp. v. United States, 363 F.2d 312, 315 (D.C. Cir. 1966).

42. Alcoa, 499 F. Supp. at 78 .

43. Id.

44. See id. at 79-80. The concept of splitting losses is not without precedent in contract law. See, e.g., Cutler v. Ellis, 1 N.J. Misc. 228, 134 A. 308 (Sup. Ct. 1923) (jury instruction on compromise verdict); Huling v. Craig, 1 Add. (5 Pa.) 342, 343 (1797) ("It must be impossibility, not difficulty, that will excuse from performance of a contract. If complete performance became impossible from a cause not within the power of man to control, the loss ought perhaps to be divided."). But see Piaggio v. Somerville, 119 Miss. 6 , 80 So. 342 (1919) (court rejects offer to pay part of loss; holds that breaching party must pay entire loss); Wood v. Bartolino, 48 N.M. 175, 185, 146 P.2d 883, 886 (1944) (landlord not required to share tenant's losses caused by wartime regulations, though evidence that landlords generally did so). In Pollard $v$. Shaffer, 1 Dall. 210 (Pa. 1787), the court held that the acts of the British army in occupying Philadelphia did not excuse the tenant from an obligation to pay rent. The court held that the tenant would be excused from obligation to return the premises in good repair. The court explained its result this way: "Because equality is equity, and the loss should be divided-he who had the term will lose the temporary profits of the premises, and he who hath the reversion, will bear the loss done to the permanent buildings." Id. at 215.

Cf. Iowa Elec. Light \& Power Co. v. Atlas Corp., 467 F. Supp. 129, 135-36 (N.D. Iowa 1978) (court denied excuse based on added costs of uranium. The court noted, however, that U.C.C. $\S 2-716$ (specific 
trine. The future is a doctrine of contract with a greater element of societal norms than at present. That possible future may materialize regardless of how contracting parties act today. That future is likely to arrive even sooner for parties, such as those in the construction industry, who choose to leave significant gaps in their contracts. 